\title{
Paleomagnetism of the Front Range (Colorado) Morrison Formation and an alternative model of Late Jurassic North American apparent polar wander
}

\author{
Mickey C. Van Fossen, Dennis V. Kent \\ Lamont-Doherty Geological Observatory and Department of Geological Sciences, Columbia University
}

Palisades, New York 10964

\begin{abstract}
A paleomagnetic study of the Upper Jurassic Morrison Formation in the Front Range of central Colorado yields high-unblockingtemperature, dual-polarity magnetizations. With respect to known paleohorizontal, the inclinations (absolute mean $=57.3^{\circ}, 95 \%$ confidence interval $=52.3^{\circ}$ to $63.1^{\circ}, N=8$ sites) pass tilt and reversal tests, whereas the dispersion in declinations can be attributed to apparent or real tectonic rotations and sedimentary processes. The site-centered colatitudinal locus of possible Front Range Morrison poles partially overlaps the "upper" pole, but it excludes the "lower" pole from the Morrison Formation on the Colorado Plateau as well as the $151 \mathrm{Ma}$ Glance conglomerate pole from the Basin and Range province of southeastern Arizona. We offer various explanations for these disparities and suggest an alternative model of Late Jurassic North American apparent polar wander through $\sim 70^{\circ} \mathrm{N}$ which is supported by Late Jurassic European poles (with positive stability tests) transferred to North American coordinates.
\end{abstract}

\section{INTRODUCTION}

The early paleomagnetic study by Steiner and Helsley (1975) of the flat-lying, Upper Jurassic Morrison Formation near Norwood on the Colorado Plateau in southwestern Colorado yielded distinct pole positions from lower and upper parts of the rock unit. The Morrison poles have taken on a renewed importance in North American paleomagnetism because they virtually define the Late Jurassic through Early Cretaceous track of apparent polar wander according to May and Butler (1986). The Late Jurassic through Early Cretaceous track has critical implications for the motion of western Cordillera suspect terranes because it predicts rapid northward motion for cratonic North America (e.g., May et al., 1989; Butler et al., 1991). Geissman and Gordon (1991) have already hinted at possible overprinting problems with the Morrison poles. Given the importance of these data, we sampled the Morrison Formation at 15 sites in a different setting, in the Front Range of Colorado (off the Colorado Plateau), where a fold test for paleomagnetic stability could be applied.

Lacustrine and fluvial deposits of the Morrison Formation are widely distributed in the Western Interior, covering a region both on and off the Colorado Plateau. Along the north-south-trending eastern foothills of the Front Range of central Colorado (Fig. 1), the Morrison Formation is part of an Upper Permian to lower Tertiary sedimentary sequence that was variably tilted and faulted during Laramide uplift of Precambrian basement blocks (Boos and Boos, 1957). The oldest angular unconformity above the Upper Jurassic Morrison Formation occurs in the Dawson arkose, indicating a Late Cretaceous age for the beginning of Laramide deformation in the Front Range (Kluth and Nelson, 1988).

Along the eastern foothills, the Morrison Formation varies in lithology from indurated, medium gray limestone at the Big Thompson upright anticline along Highway 34 (sampling sites $\mathrm{A}-\mathrm{H}$ ), red to purple shale and $\tan$ siltstone that dip homoclinally to the east by $\sim 35^{\circ}$, about $20 \mathrm{~km}$ southwest of Denver on county Highway 26 (sites I-K), and red to tan siltstone along Skyline Drive and in Oil Creek north of Canon City, where

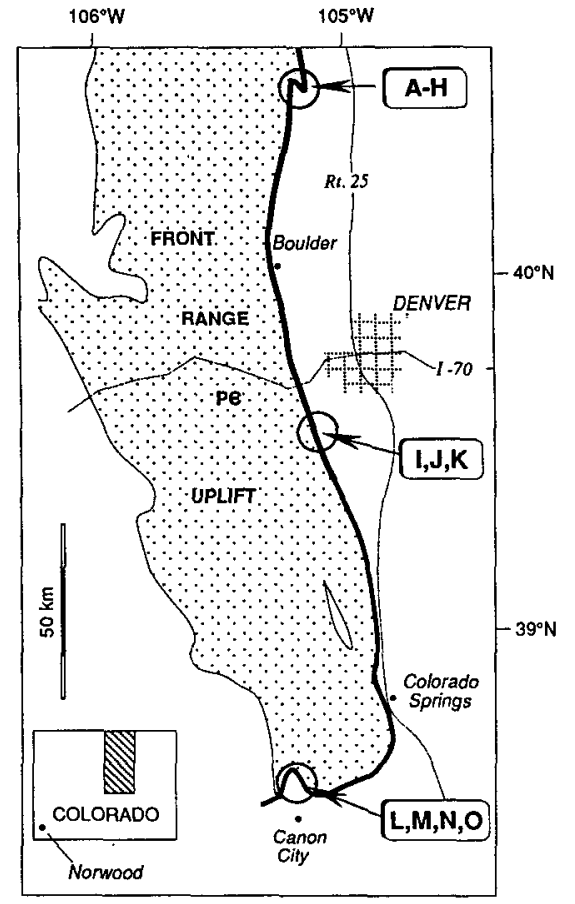

Figure 1. Sketch map of Front Range Precambrian uplift, central Colorado. Bold curve outlines outcrop of tilted Paleozoic through Tertiary strata in eastern foothills which includes Morrison Formation. Paleomagnetic sampling sites A-O are indicated.

the structure is characterized by a series of folds plunging to the southeast by $<10^{\circ}$ (sites L-O) (Fig. 1).

Imlay (1980) estimated the Morrison age range as late Oxfordian to early Tithonian. In the Canon City region (Fig. 1), Schultze and Enciso (1983) have described a Callovian fish bed in the "Ralston Creek" formation conformably overlain by the Morrison Formation. Thus, an approximate age of late Oxfordian for the base of the Morrison Formation in the Front Range would be compatible with the estimate of Imlay (1980). Exposures of Front Range Morrison rocks limited our sampling to nominally the lower half of the formation, so the age of the sampling interval is estimated as late Oxfordian through Kimmeridgian (156 to $152 \mathrm{Ma}$; Harland et al., 1990), which should correlate in general stratigraphic terms with at least the lower part of the Morrison Formation at Norwood.

\section{PALEOMAGNETISM}

Progressive thermal and alternating field demagnetization of samples from all seven Denver and Canon City sites where the Morrison rocks are reddish yielded a single magnetization component of high unblocking temperature and high coercivity with normal and reversed polarity in different samples (Fig. 2). Alternating fields to $100 \mathrm{mT}$ have little effect on the magnetizations, and, in conjunction with peak unblocking temperatures of $670^{\circ} \mathrm{C}$, suggest hematite as a carrier of the remanence. There appears to be no evidence for a significant secondary contamination that can be distinguished from the characteristic high-unblocking-temperature magnetizations that were isolated in $61 \%$ of the Denver and Canon City 
samples (typically 4-5 per site). The remaining samples, especially tan siltstone, mostly showed unstable response to progressive thermal demagnetization (e.g., principal component analysis [Kirschvink, 1980] gave mean angular deviation values $>15^{\circ}$ ), although three samples at site $M$ and one at site $\mathrm{N}$ contained a stable magnetization component with a curious direction of northwesterly and steeply negative $\left(\sim-60^{\circ}\right)$.

Of the eight limestone sites from the Big Thompson anticline, only site $\mathbf{G}$ was salvageable: all other limestone samples showed the unstable response to both demagnetization methods. The magnetization from site $G$ (uniform normal polarity) is similar in direction to the characteristic magnetization found in the Denver and Canon City rocks, and its peak unblocking temperatures of $\sim 650{ }^{\circ} \mathrm{C}$ and moderate to high coercivities (median destructive fields $=50$ to $70 \mathrm{mT}$ ) also suggest hematite as the main carrier of remanence.

The sample characteristic magnetizations were averaged by site with standard Fisher (1953) statistics, yielding eight site mean directions for the Morrison Formation (Table 1; Fig. 3). Two of the sites (I and J) each contain a single sample with polarity opposite to that of the remaining samples in the site and pass the reversal test for isolated observations (McFadden and McElhinny, 1990). The eight site means group equally well before (declination/inclination $[\mathrm{D} / \mathrm{I}]=313.0 / 46.9, k=25, \alpha_{95}=$ $11.2^{\circ}$ ) and after rotation of bedding planes back to horizontal about strike $\left(\mathrm{D} / \mathrm{I}=352.3 / 60.8, k=21, \alpha_{95}=12.5^{\circ}\right)$, with no significant peak in precision parameter at intermediate bedding corrections. Most of the variability after bedding tilt correction is in the declinations that are distributed

Figure 2. Representative orthogonal vector endpoint diagrams of thermal demagnetization of normal remanent magnetization (NRM) in Front Range Morrison Formation samples, in situ coordinates. A: Red siltstone, Denver site I. B: Tan siltstone, Canon City site N. Open symbols plotted on vertical plane; solid symbols plotted on horizontal plane. Tick marks at $1 \mathrm{~mA} / \mathrm{m}$ intervals.

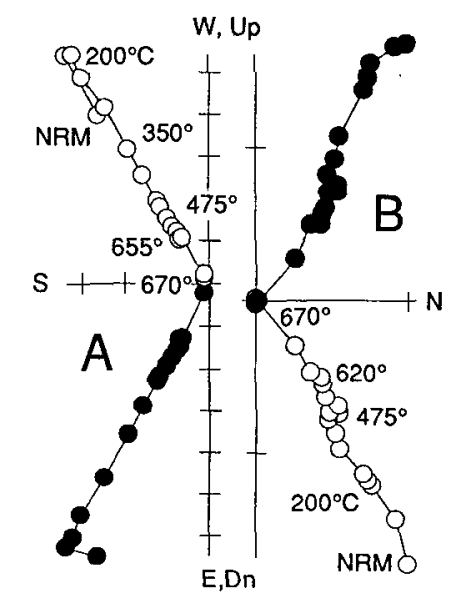

TABLE 1. SUMMARY OF MEAN DATA, FRONT RANGE MORRISON FORMATION

\begin{tabular}{|c|c|c|c|c|c|c|c|c|}
\hline \multirow[b]{2}{*}{ Site } & \multirow[b]{2}{*}{$\mathrm{N}$} & \multirow[b]{2}{*}{$\mathbf{k}$} & \multirow[b]{2}{*}{$\alpha 95$} & \multicolumn{2}{|c|}{ In situ } & \multicolumn{2}{|c|}{ Paleohorizontal* } & \multirow[b]{2}{*}{ Strike/Dip } \\
\hline & & & & Dec. & Inc. & Dec. & Inc. & \\
\hline $\bar{G}$ & 4 & 70 & 11.0 & 305.2 & 48.1 & 322.7 & 61.4 & $001 / 18 \mathrm{E}$ \\
\hline I & 3 & 32 & 22.0 & 121.9 & -40.0 & 154.6 & -55.9 & $346 / 32 \mathrm{E}$ \\
\hline $\mathrm{J} \dagger$ & 4 & 14 & 25.3 & 309.1 & 55.0 & 11.0 & 62.9 & $351 / 35 \mathrm{E}$ \\
\hline $\mathrm{K}^{\dagger}$ & 4 & 40 & 14.6 & 344.4 & 63.1 & 33.9 & 47.5 & $346 / 35 E$ \\
\hline $\mathrm{L}$ & 5 & 30 & 14.2 & 292.7 & 28.3 & 317.5 & 61.8 & $359 / 40 \mathrm{E}$ \\
\hline $\mathrm{M}$ & 3. & 66 & 15.2 & 150.6 & -53.7 & 209.2 & -53.0 & $359 / 40 \mathrm{E}$ \\
\hline $\mathrm{N}$ & 5 & 100 & 7.7 & 308.9 & 40.9 & 359.2 & 59.6 & $357 / 42 \mathrm{E}$ \\
\hline 0 & 5 & 17 & 18.9 & 149.5 & -37.6 & 136.8 & -53.9 & $090 / 20 \mathrm{~S}$ \\
\hline
\end{tabular}

Full vector formation means:

$\begin{array}{llllllll}\text { In situ } & (8) & 25 & 11.2 & 313.0 & 46.9 & & \\ \text { Paleohori. }{ }^{*(8)} & 21 & 12.5 & - & - & 352.3 & 60.8\end{array}$

Inclination-only data (using method of McFadden and Reid [1982]): In situ (8) Mean $=46.9^{\circ}$ (confidence interval: $\left.36.5^{\circ}-59.4^{\circ}\right) \mathrm{k}=26$ Paleohori. ${ }^{*}(8) \quad$ Mean $=57.3^{\circ}$ (confidence interval: $52.3^{\circ}-63.1^{\circ}$ ) $\mathrm{k}=114$

POLE $\$ \quad 83.7^{\circ} \mathrm{N}, 150.4^{\circ} \mathrm{E}\left(\mathrm{dp}=14^{\circ}, \mathrm{dm}=19^{\circ}\right)$

Note: $\mathrm{N}$, number of sample (site mean) directions used in calculation; $\mathrm{k}$, Fisher precision parameter, $\alpha 95$, radius of cone of $95 \%$ confidence; Dec., Inc., declination and inclination; dp, dm, semi-axes of $95 \%$ confidence ellipse parallel and perpendicular to, respectively, site-to-pole meridian.

*Paleohorizontal = bedding planes rotated to horizontal about strike.

tSite contains one sample magnetization of opposite polarity.

§Pole calculated using Dec/Inc $=352.3^{\circ} / 57.3^{\circ}$ over $70^{\circ}$ among the three sampling localities (Big Thompson, Denver, and Canon City) but also within the Denver (sites I, J, and K) and Canon City (L-O) localities (Fig. 3).

In contrast, an examination of the inclination data according to the method of McFadden and Reid (1982) shows they are well grouped after bedding tilt correction $(k=114)$, with an unbiased mean absolute inclination of $57.3^{\circ} \pm 5.8^{\circ} / 5.0^{\circ}$ for $N=8$ sites (Table 1; Fig. 3). The precision parameter is 4.3 times greater than before bedding tilt correction $(k=26)$, suggesting a positive tilt test significant at the $95 \%$ confidence level based on the $f$-ratio criterion (McElhinny, 1964). The bedding tilt-corrected means by polarity of $57.7^{\circ} \pm 5.3^{\circ} / 3.4^{\circ}$ ( 22 normal polarity samples) and $-54.0^{\circ} \pm-7.5^{\circ} /-5.9^{\circ}$ ( 11 reversed polarity samples) are, moreover, within $3.7^{\circ}$ of antipodality with overlapping confidence intervals, suggesting a positive reversal test on the basis of inclination.

The consistency of magnetizations with respect to known paleohorizontal, with positive tilt and reversal tests on inclination data, combined with the lack of discernible magnetic overprinting, argues for acquisition of the characteristic magnetizations prior to Late Cretaceous Laramide deformation and perhaps closely associated with deposition of the Front Range Morrison Formation. The dual polarities and positive reversal test also suggest that the magnetizations were acquired over a sufficient amount of time for averaging of secular variation, and that any polaritydependent contamination bias in the magnetizations is insignificant. The dispersion in declination is presumably due to some combination of apparent or real tectonic rotations between localities (MacDonald, 1980), as well as sedimentary processes during magnetization acquisition even within localities such as have been observed in modern hematite-bearing deposits (Tauxe and Kent, 1984).

The mean inclination of $57.3^{\circ} \pm 5.8^{\circ} / 5.0^{\circ}$ converted to a site-centered colatitude (nominal site location $=$ lat $40^{\circ} \mathrm{N}$, long $255^{\circ} \mathrm{E}$, colatitude $=$ $52.1^{\circ}$ ) describes a locus of possible Front Range Morrison pole positions with associated $95 \%$ confidence interval (Fig. 4). The declination data provide what we regard as conservative sector constraints on the locus (Fig. 4); i.e., the true Front Range Morrison pole would likely fall within this sector if full compensation for structural and/or sedimentary effects on the horizontal component of magnetization could be achieved. The pole sector is confined to high latitudes, greater than $\sim 67^{\circ} \mathrm{N}$, and any possible inclination shallowing due to sedimentary processes would bring the pole sector to an even higher latitude. Note that in geographic coordinates (without bedding tilt correction), the pole $\left(49.8^{\circ} \mathrm{N}, 163.0^{\circ} \mathrm{E}, \mathrm{dp}=9.3^{\circ}, \mathrm{dm}\right.$ $=14.5^{\circ}$ ) and locus of possible poles based on inclination data (colatitude $=$ $62.0^{\circ}$ ) fall far from Late Cretaceous to Holocene North American poles (Irving and Irving, 1982), supporting the conclusion drawn from the tilt test that a post-Laramide remagnetization of the Front Range Morrison Formation can be dismissed.



Figure 3. Site mean directions from Front Range Morrison Formation; open symbols plotted on upper hemisphere of equal-area projection; solid symbols plotted on lower hemisphere. A: In situ coordinates. B: Bedding tittcorrected coordinates with antipodes of three reversed site means (triangles). Shaded area indicates mean absolute inclination $\left(57.3^{\circ}\right)$ and 95\% confidence region using method of McFadden and Reid (1982). 


\section{COMPARISON WITH PUBLISHED MORRISON POLES}

Even without the sector constraints, the colatitude locus of Front Range Morrison pole positions excludes the lower Morrison pole $\left(61.4^{\circ} \mathrm{N}\right.$, $142.2^{\circ} \mathrm{E}$ ) but overlaps the $95 \%$ confidence ellipse of the upper Morrison pole $\left(67.5^{\circ} \mathrm{N}, 161.8^{\circ} \mathrm{E}\right)$ of Steiner and Helsley (1975). One would arrive at the same conclusion if these Norwood Morrison poles are corrected as in May and Butler (1986), and henceforth in this paper, for $\sim 4^{\circ}$ of clockwise rotation of the Colorado Plateau (lower Morrison $58.6^{\circ} \mathrm{N}, 146.2^{\circ} \mathrm{E}$; upper Morrison $64.6^{\circ} \mathrm{N}, 164.2^{\circ} \mathrm{E}$ ) (Fig. 4). Within the broad uncertainties in age and regional correlation of the Morrison Formation (e.g., Steiner [1980] correlated the Norwood magnetostratigraphy to M25-M22 [155-149 Ma], whereas May and Butler [1986] favored M19-M16 [146-141 Ma]), we expected the Front Range results to correspond at least in part with the lower Morrison pole, yet clearly there is a discrepancy. The lower Morrison pole may indicate more complicated Late Jurassic

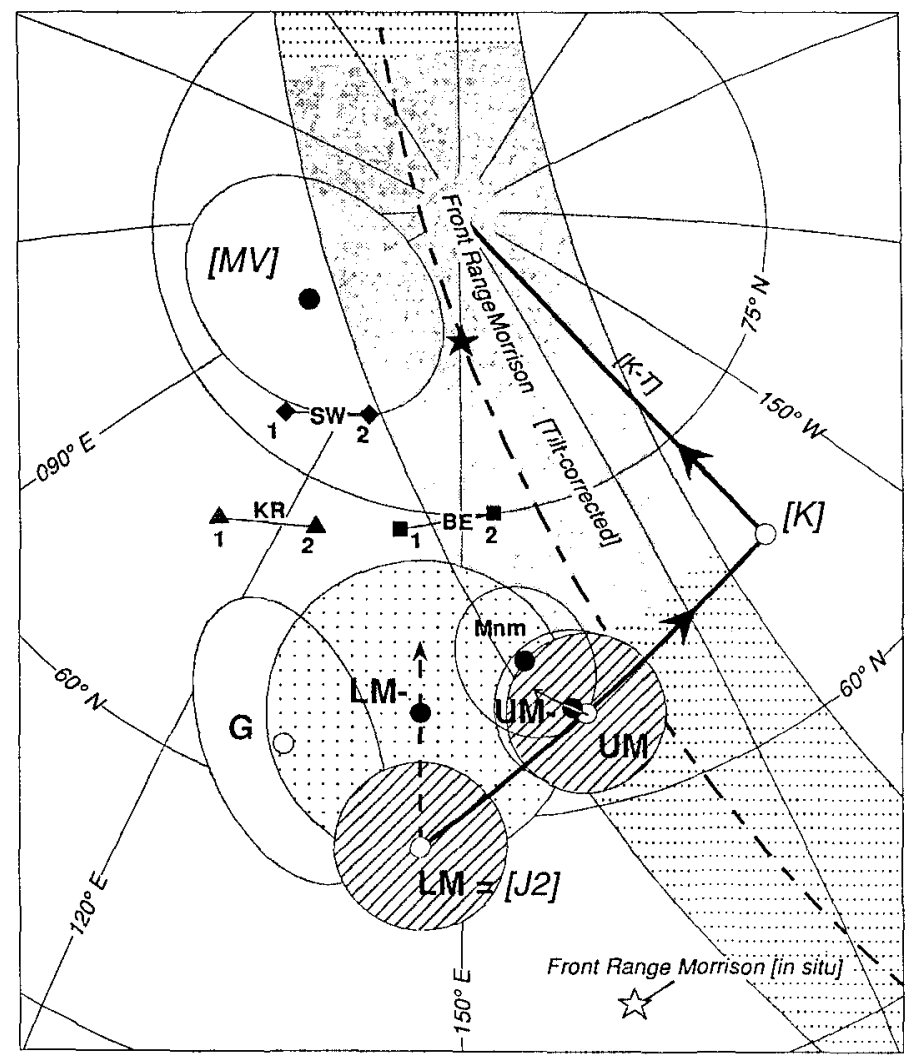

Figure 4. Locus of possible Front Range Morrison poles based on bedding tilt-corrected inclinations (dashed heavy line with associated $95 \%$ confidence band [stipple]), with most likely pole sector using declination data (dense stipple). Front Range Morrison poles calculated in conventional fashion from full vector data shown by solid star (bedding tilt-corrected) and open star (in situ coordinates). These results are compared to paleomagnetic poles with $95 \%$ contidence intervals from upper Morrison (UM) and lower Morrison (LM) from Norwood reported by Steiner and Helsley (1975) and using less tiltered data (UM- and LM-, respectively), all corrected for $4^{\circ}$ of Colorado Plateau rotation as in May and Butler (1986), and preliminary Morrison Formation result in northeast New Mexico (Mnm; Steiner et al., 1989). Also shown are 151 Ma Glance conglomerate pole (G; Kluth et al., 1982) and 166 Ma Moat volcanics pole (MV; Van Fossen and Kent, 1990). Heavy lines show Late Jurassic-Early Cretaceous (J2-K) apparent polar wander track of May and Butler (1986) and continuation of North American path through Tertiary (K-T), portrayed diagrammatically after Irving and Irving (1982). European poles with stability tests transferred to North American coordinates using two alternative Laurasian reconstructions are signified by: $\mathbf{S W}=$ Oxfordian Swiss Jura pole (Johnson et al., 1984); KR = Callovian Krakow Upland pole (Kadzialko-Hofmokl and Kruczyk, 1987); and BE = Early Cretaceous Berrias pole (Galbrun, 1985). Reconstructions: (1) Bullard et al. (1965), (2) Savostin et al. (1986).
North American apparent polar wander, but there are indications in the study by Steiner and Helsley (1975) for an alternative explanation for the Norwood data.

Our paleomagnetic study of the Front Range Morrison yielded magnetizations with relatively steep inclination $\left(-57^{\circ}\right)$, which would also be expected of coeval Morrison rocks in nearby Norwood, Colorado. Steiner and Helsley (1975), however, preferentially rejected for pole calculation the normal polarity samples with steep inclination, leaving, of the 425 samples analyzed for magnetostratigraphy, 32 samples for calculation of the lower Morrison pole and 68 samples for the upper Morrison pole. This rejection criterion for pole calculation was destined to leave normalpolarity magnetizations with only relatively shallow inclination. At the same time, a relatively steep normal-polarity overprint contamination would tend to shallow the reversed polarity magnetizations, thus making them more nearly antipodal to the filtered, shallow normal magnetizations. Therefore, we suggest that the shallowing effect from filtered normal and overprinted reversed magnetizations led to a bias in the Norwood Morrison poles to lower latitudes. Moreover, the "more prevalent" magnetic contamination in the lower part of the Norwood section noted by Steiner (1980) might account for the even lower latitude pole from the lower Morrison reported by Steiner and Helsley (1975).

Some indication of the filtering effect is illustrated by the appreciable change of the lower Morrison pole position when the less filtered data available in Steiner and Helsley (1975) are used. The six (four normal, two reversed) lower Morrison polarity interval means give a lower Morrison pole $\sim 8^{\circ}$ farther north at $65.2^{\circ} \mathrm{N}, 145.2^{\circ} \mathrm{E}$, closer to the Front Range Morrison pole sector but also in better agreement with the Norwood upper Morrison pole (Fig. 4). In fact, if the less severely selected lower and upper Morrison data in Steiner and Helsley (1975) are combined, the magnetizations pass a reversal test at the $95 \%$ confidence level (class B; McFadden and McElhinny, 1990). The resultant pole $\left(69.2^{\circ} \mathrm{N}, 147.1^{\circ} \mathrm{E}, \mathrm{dp}=4.0, \mathrm{dm}\right.$ $=6.0$ ) falls within the fringes of the Front Range Morrison sector and is very close to a preliminary Morrison pole reported from northeast New Mexico $\left(67.6^{\circ} \mathrm{N}, 158.1^{\circ} \mathrm{E}\right.$; Steiner et al., 1989; Fig. 4). We would therefore suggest that if the shallowing effect on the reversed magnetizations could be quantitatively modeled, and/or compensated by thermally demagnetized but unfiltered normal polarity data, the resultant lower and upper Morrison poles from Norwood would converge and be indistinguishable, and even come into complete agreement with the Front Range Morrison pole sector. Thus, pending a paleomagnetic restudy of the Morrison strata at Norwood, a single Morrison Formation pole at a minimum latitude of $\sim 68^{\circ} \mathrm{N}$, in the vicinity of the Front Range Morrison pole sector, cannot be precluded on the basis of the available information.

\section{DISCUSSION}

This evidence for a single, higher latitude Morrison Formation pole is ostensibly at odds with the lower latitude Glance conglomerate pole from southern Arizona $\left(62.2^{\circ} \mathrm{N}, 130.3^{\circ} \mathrm{E}, \mathrm{dp}=4.1, \mathrm{dm}=7.4\right.$; Kluth et al, 1982), the remaining Late Jurassic North American pole deemed reliable in recent apparent polar wander syntheses (May and Butler, 1986; Van der Voo, 1990). The Rb/Sr date of $151 \mathrm{Ma}$ for the Glance pole makes it near to or within the estimated age range for the Morrison Formation, yet the minimum arc distance between the Glance pole and our Front Range Morrison pole locus or sector is $17^{\circ}$ (Fig. 4). However, the significance of this discordance is unclear, because the post-Jurassic tectonic coherence of southern Arizona is now a matter of debate (see Butler et al., 1992; Van Fossen and Kent, 1992).

In the absence of any other Late Jurassic North American poles regarded as reliable in recent apparent polar wander syntheses, poles from other continents can be compared to the North American data by using published reconstructions. Eurasia is well represented by paleopoles for this general time interval, and from a recent comprehensive compilation by Van der Voo (1990), we selected the two published results supported by stability tests; the Swiss Jura pole (Johnson et al., 1984) and the 
Krakow Upland pole (Kadzialko-Hofmokl and Kruczyk, 1987). The Oxfordian Swiss Jura blue limestones give a pole position at $78^{\circ} \mathrm{N}, 148^{\circ} \mathrm{E}$ $\left(\alpha_{95}=6^{\circ}\right)$ with a positive fold test. Results from Callovian limestones of the Krakow Upland pass a reversal test (class $\mathrm{C}$ ) and give a pole at $72^{\circ} \mathrm{N}$, $150^{\circ} \mathrm{E}\left(\alpha_{95}=7^{\circ}\right)$. To bracket the possible younger age range for the Morrison Formation, we include the Early Cretaceous (Berriasian) pole from Berrias, France, which passes a class $\mathrm{C}$ reversal test $\left(75^{\circ} \mathrm{N}, 179^{\circ} \mathrm{E}\right.$, $\alpha_{95}=3^{\circ}$; Galbrun, 1985).

We have rotated the Krakow, Jura, and Berrias poles to North American coordinates using the two alternative reconstructions (Bullard et al., 1965; Savostin et al., 1986) favored by Van der Voo (1990). The alternative reconstructions mainly affect the longitude of the transferred poles. Hence, the transferred Krakow and Jura poles fall along latitudes of nominally $75^{\circ} \mathrm{N}$ regardless of the preferred reconstruction, in the vicinity of the Front Range Morrison pole sector but significantly north of the Norwood Morrison and Glance poles (Fig. 4). Furthermore, we note that the Berrias pole transferred from Europe also falls at high latitude ( $71^{\circ}-75^{\circ} \mathrm{N}$; Fig. 4).

The Front Range Morrison pole sector, supported by transferred European poles, suggests that the Late Jurassic pole for North America was at least as far north as $68^{\circ} \mathrm{N}$ (Fig. 4). This is consistent with the high-latitude pole position we have suggested for the Middle Jurassic (Van Fossen and Kent, 1990), but clearly different from the lower latitude Late Jurassic through Early Cretaceous track (May and Butler, 1986). Thus, whereas the Late Jurassic-Early Cretaceous track would suggest that cratonic North America was moving northward by $\sim 15^{\circ}$ during the Late Jurassic and Early Cretaceous, our alternative path suggests that the craton had already attained a more northerly latitude by the Middle Jurassic and remained at that latitude into the Late Jurassic.

Finally, we note that while this interpretation is based on just one Late Jurassic result, which requires confirmation, it has fundamental implications in plate-tectonic studies such as the paleomagnetic analysis of Cordilleran suspect terranes. For example, the recent analytical review by Butler et al. (1991) indicated virtually concordant Late Jurassic paleolatitudes for the Vizcaino (Baja California peninsula) and Stanley Mountain (southern California) terranes using the Glance pole for reference, yet significantly discordant mid-Cretaceous paleolatitudes $\left(12^{\circ} \pm 4^{\circ}\right.$ and $38^{\circ}$ $\pm 6^{\circ}$ farther south, respectively) using the well-established mid-Cretaceous reference pole for the North American craton. However, if the higher latitude paleopole option presented in this study were used, Late Jurassic paleolatitudes for the Vizcaino and Stanley Mountain terranes would also be discordant (by $\sim 11^{\circ}$ to the south), more compatible with at least the sense of discordance suggested by the mid-Cretaceous paleomagnetic data (see also Beck, 1991).

\section{REFERENCES CITED}

Beck, M.E., Jr., 1991, Case for northward transport of Baja and coastal southern California: Paleomagnetic data, analysis, and alternatives: Geology, v. 19, p. 506-509.

Boos, C.M., and Boos, M.F., 1957, Tectonics of eastern flank and foothills of Front Range, Colorado: American Association of Petroleum Geologists Bulletin, v. 41, p. 2603-2676.

Bullard, E.C., Everett, J.E., and Smith, A.G., 1965, A symposium on continental drift; IV, The fit of the continents around the Atlantic: Royal Society of London Philosophical Transactions, ser. A, v. 258, p. 41-51.

Butler, R.F., Dickinson, W.R., and Gehrels, G.E., 1991, Paleomagnetism of coastal California and Baja California: Alternatives to large-scale northward transport: Tectonics, v. 10 , p. $561-576$

Butler, R.F., May, S.R., and Bazard, D.R., 1992, Comment on "High-latitude paleomagnetic poles from Middle Jurassic plutons and Moat Volcanics in New England and the controversy regarding Jurassic apparent polar wander for North America" by Mickey C. Van Fossen and Dennis V. Kent: Journal of Geophysical Research (in press).

Fisher, R.A., 1953, Dispersion on a sphere: Royal Society of London Proceedings, ser. A, v. 217 , p. $295-305$.

Galbrun, B., 1985, Magnetostratigraphy of the Berriasian stratotype section (Berrias, France): Earth and Planetary Science Letters, v. 74, p. 130-136.

Geissman, J.W., and Gordon, R.G., 1991, Paleomagnetic reference poles, apparent polar wander paths, paleomagnetic Euler pole analysis, and true polar wander: Reviews of Geophysics, supplement, v. 29, p. 384-394.

Harland, W.B., Armstrong, R.L., Cox, A.V., Craig, L.E., Smith, A.G., and Smith, D.G., 1990, A geologic timescale 1989: New York, Cambridge University Press, $263 \mathrm{p}$

Imlay, R.W., 1980, Jurassic paleobiogeography of the coterminous United States in its continental setting: U.S. Geological Survey Professional Paper 1062, 134 p.

Irving, E., and Irving, G.A., 1982, Apparent polar wander paths Carboniferous through Cenozoic and the assembly of Gondwana: Geophysical Surveys, v. 5, p. 141-188.

Johnson, R.J.R., Van der Voo, R., and Lowrie, W., 1984, Paleomagnetism and late diagenesis of Jurassic carbonates from the Jura Mountains, Switzerland and France: Geological Society of America Bulletin, v. 95, p. 478-488.

Kadzialko-Hofmokl, M., and Kruczyk, J., 1987, Paleomagnetism of middle-late Jurassic sediments from Poland and implications for the polarity of the geomagnetic field: Tectonophysics, v. 139, p. 53-66.

Kirschvink, J.L., 1980, The least-squares line and plane and the analysis of paleomagnetic data: Royal Astronomical Society Geophysical Journal, v. 62, p. 699-718.

Kluth, C.F., and Nelson, S.N., 1988, Age of the Dawson arkose, Southwestern Air Force Academy, Colorado, and implications for the uplift history of the Front Range: Mountain Geologist, v. 25, p. 29-35.

Kluth, C.F., Butler, R.F., Harding, L.E., Shafiqulah, M., and Damon, P.E., 1982, Paleomagnetism of Late Jurassic rocks in the northern Canelo Hills, southeastern Arizona: Joumal of Geophysical Research, v. 87, p. 7079-7086.

MacDonald, W.D., 1980, Net tectonic rotation, apparent tectonic rotation, and the structural tilt correction in paleomagnetic studies: Journal of Geophysical Research, v. 85, p. $3659-3669$.

May, S.R., and Butler, R.F., 1986, North American Jurassic apparent polar wander, implications for plate motion, paleogeography and Cordilleran tectonics: Journal of Geophysical Research, v. 91, p. 11,519-11,544.

May, S.R., Beck, M.E., and Butler, R.F., 1989, North American apparent polar wander, plate motion, and left-oblique convergence: Late Jurassic-Early Cretaceous orogenic consequences: Tectonics, v. 8, p. 443-451.

McElhinny, M.W., 1964, Statistical significance of the fold test in paleomagnetism: Royal Astronomical Society Geophysical Journal, v. 8, p. 338-340.

McFadden, P.L., and McElhinny, M.W., 1990, Classification of the reversal test in palaeomagnetism: Geophysical Journal International, v. 103, p. 725-729.

McFadden, P.L., and Reid, A.B., 1982, Analysis of paleomagnetic inclination data: Royal Astronomical Society Geophysical Joumal, v. 69, p. 307-319.

Savostin, L.A., Sibuet, J.C., Zonenshain, L.P., Le Pichon, X., and Roulet, M.J., 1986, Kinematic evolution of the Tethys Belt from the Atlantic Ocean to the Pamirs since the Triassic: Tectonophysics, v. 123, p. 1-35.

Schultze, H., and Enciso, G., 1983, Middle Jurassic age of the fish-bearing horizon in the Canon City embayment, Colorado: Journal of Paleontology, v. 57, p. 1053-1060.

Steiner, M.B., 1980, Investigation of the geomagnetic field polarity during the Jurassic: Journal of Geophysical Research, v. 85, p. 3572-3586.

Steiner, M.B., and Helsley, C.E., 1975, Reversal pattern and apparent polar wander for the Late Jurassic: Geological Society of America Bulletin, v. 86, p. $1537-1543$.

Steiner, M.B., Lawrence, S., and Beck, M., 1989, A Jurassic pole position from the craton of North America: Eos (Transactions, American Geophysical Union), v. 70 , p. 600 .

Tauxe, L., and Kent, D.V., 1984, Properties of a detrital remanence carried by haematite from study of modern river deposits and laboratory redeposition experiments: Royal Astronomical Society Geophysical Journal, v. 77, p. 543-561.

Van der Voo, R., 1990, Phanerozoic paleomagnetic poles from Europe and North America and comparisons with continental reconstructions: Reviews of Geophysics, v. 28, p. 167-206.

Van Fossen, M.C., and Kent, D.V., 1990, High latitude paleomagnetic poles from Middle Jurassic plutons and Moat Volcanics in New England and the controversy regarding Jurassic apparent polar wander for North America: Journal of Geophysical Research, v. 95, p. 17,503-17,516.

1992, Reply to Comment by Butler et al.: Journal of Geophysical Research (in press).

\section{ACKNOWLEDGMENTS}

Funded by National Science Foundation grant EAR 88-03814. We thank Bill Witte for reviewing an early version of this manuscript and Neil Opdyke for telling us about outcrops in the Front Range. Lamont-Doherty Geological Observatory Contribution No. 4866.

Manuscript received August 16, 1991

Revised manuscript received December 9, 1991

Manuscript accepted December 11, 1991 